DOI: https://doi.org/10.46630/phm.12.2020.48

Адријана М. Марчетић

Универзитет у Београду

Филолошки факултет
Оригинални научни рад УДК 821.163.41.09 Милићевић В.

Примљен: 23. 11. 2019.

\title{
НАРАТИВНИ ПОСТУПЦИ У ПРОЗИ ВЕЉКА МИЛИЋЕВИЋА (2)
}

Рад у целини посвећен је анализи и тумачењу прозе Вељка Милићевића. Док је у претходном делу рада фокус био на рецепцији Милићевићеве прозе у српској критици, као и на његовим раним приповеткама, у овом делу рада средиште интересовања је на Милићевићевом кратком роману, Беспуће. Испитујући Милићевићеве наративне технике помоћу којих представља унутрашњи живот својих јунака, доживљени говор и фокализовани опис, настојим да укажем на главне особине његове иновативне и уметнички изузетно успеле прозе. У закључку, формулишем тумачење овог, најзначајнијег Милићевићевог романа које се донекле разликује од традиционалних интерпретација.

Кључне речи: Вељко Милићевић, „Беспуће“, доживљени говор, фокализовани опис, човек без корена

На унутрашњи живот као на нову тему Милићевићеве прозе критика је од Скерлића до Витошевића често указивала, баш као што је готово једногласно истицала „зрелост” и лепоту Милићевићевог стила. Али, говорећи о лепоти Милићевићевог стила, критичари су пропустили да укажу у чему се тачно састоји његова приповедачка уметност, односно каквим се он поступцима служи да би предочио тај нови психолошки садржај, мисли и осећања својих личности. Наиме, као што смо већ казали, нову тему у Милићевићвој прози пратила је и једна нова приповедна техника, коју ћемо за ову прилику назвати „објективним” приповедањем у трећем лицу. То је приповедање из којег су уклоњени очигледни знаци приповедачевог присуства, дигресије, екстензивни коментари и обраћања читаоцу, а збивања су предочена „објективно”, на драмски начин, из перспективе неког од јунака, без пишчевог уплитања. У класичном западноевропском романима, на пример, код Флобера и Золе, „објективни" начин приповедања по правилу је удружен с једном од најважнијих психонаративних техника - са доживљеним говором (erlebte Rede) или

${ }^{1}$ adrijana.marcetic61@gmail.com 
слободним индиректним стилом (le style indirect libre). Такав је случај и код Вељка Милићевића. У његовим причама и романима, од „Мртвог живота” до Опсена, слободни индиректни стил, у контексту „објективног” приповедања у трећем лицу, представља доминантну наративну норму. Наравно, и код ранијих српских приповедача и романсијера могли би се наћи примери оваквог приповедања, али тешко да има иједног пре Милићевића који је доживљени говор доследно примењивао у том обиму и на тај начин, у вези са новом тематиком, психолошким доживљајем јунака. Милићевићу је ова техника главно средство помоћу којег дочарава развој и зрење унутрашњег доживљаја јунака; експериментишући, он ју је временом усавршавао, обогаћујући на тај начин и сопствени стил и изражајне могућности српске прозе уопште.

Слободном индиректном стилу Милићевић се учио првенствено од француских писаца, Флобера и Мопасана, али та чињеница ни најмање не умањује вредност његове прозе. Штавише, задивљујуће је како је лако, природно и непретенциозно тако млад писац усвојио овај приповедни начин и с колико га је књижевног и језичког осећања применио у српском језику. За веома кратко време, од „Мртвог живота” до Бесnућа, Милићевић је постао прави мајстор ове прозне технике, а њоме се служио тако надахнуто и виртуозно да бисмо га могли назвати српским Флобером само да га је таленат мало дуже послужио и да је, после Бесnућа, написао бар још један или два романа сличне инспирације. Као једној од техника приповедања у трећем лицу, слободном индиректном стилу својствена је амбивалентност у погледу приповедне перспективе: читалац има утисак да се налази у свести јунака, односно да из његове перспективе посматра свет који га окружује и збивања у њему али, с друге стране, о тим збивањима не приповеда сам јунак, у првом лицу, као у унутрашњем монологу, већ о њима у трећем лицу извештава неименовани, безлични приповедач. Приповедач може у сопствени говор, ту и тамо, убацити и неку јунакову реч, али не у форми директног навођења, већ помешано са сопственим идиомом, такорећи препричану сопственим речима, као у неуправном говору. На овај начин приповедачев и јунаков дискурс су помешани и спојени у јединствену целину која делује стилски компактно, дотерано и уједначено, као проза у којој, флоберовски речено, ништа не штрчи.

Евоцирањем јунаковог језика и начина изражавања, у приповедању се истиче његова психолошка перспектива. У ту сврху могу послужити и још нека средства, на пример, показне заменице које указују на јунаково место у простору (физичком или социјалном), или узвици и интерпункцијски знаци (ускличници и знакови питања) који изражавају јунаков емоционални став. Будући да је доживљени говор наративни поступак 
који се у великој мери ослања на особине самог језика на којем је текст написан, он увек има и неке специфичне особине које произлазе из природе тог језика. На пример, приповедање у садашњем односно будућем времену једна је од карактеристичних особина доживљеног говора у српском језику. Све ово можемо запазити у следећим примерима, где ћемо црним истаћи речи путем којих се директно конституише доживљени говор. Први одломак је из „Мртвог живота”, други и трећи из „Вихора”, а последњи из „Млаких душа”:

Главу је поднимио у руке и наслонио се лактовима о свој сто. Гледао га је дуго. Ето, позна га у најмање ситнице, сваку резотину, сваку мрљу, црвоточину, позна на њему. Десет година свога учитељевања сједио је он ту, за својим столом. Ту су се рађале његове идеје, утопијске идеје, ту је он снивао, у сумрацима, како ће он дићи - не дићи већ ускрснути - народ, морално и материјално. Ту се он опијао славом будуће побједе за коју се он жртвовао, за коју се дао мучити, газити, пљувати... (MILIĆEVIĆ 1903: 338)

У овом примеру, одломку из „Мртвог живота”, само су прве две реченице (,Главу је поднимио у руке и наслонио се лактовима о свој сто. Гледао га је дуго.’) исприповедане с тачке гледишта неименованог приповедача, „објективним начином”. Остатак одломка, почевши од реченице „Ето, позна га у најмање ситнице...”, исприповедан је такође у трећем лицу, приповедачевим гласом, али из перспективе јунака, учитеља Дамјана Дамјановића; просторна тачка гледишта, лексика, асоцијативни оквир у целини нису приповедачеви, већ јунакови. На то упућује узвик „ето” којим почиње реченица, прилог „ту” који фокусира приповедање у просторну тачку гледишта јунака и, најзад, избор лексике којом се изражава јунакова емоционална тачка гледишта: „ту је он снивао... како ће... дићи - не дићи већ ускрснути... ". Глагол ,ускрснути”, који приповедач бира уместо неутралнијег ,дићи”, уводи читаоца у Дамјанов унутрашњи доживљај и сугерише му емоционални и морални значај који је за младог учитеља у прошлости имала идеја о просвећивању народа. Наравно, употреба овог глагола може се схватити и у нешто друкчијем, иронијском кључу, као израз приповедачевог односа према идеализму младог учитеља, али управо таква двосмисленост јесте једна од суштинских особина доживљеног говора, у којем је често немогуће успоставити јасну разлику између приповедачеве и јунакове речи, а самим тим ни определити се за једно од могућих значења исказа.

Следећа два одломка из „Вихора” прави су примери флоберовског доживљеног говора:

Немиран осјећај будио се у души Смиље Тадићеве, осјећај који она није могла испитати својим разумом, већ га је само у души појимала. Будило 
се у њој нешто што је она одавно слутила и очекивала да ће доћи, и то је избијало на површину тек у ноћи, топлој и мекој, страсној и разблудној. Дању рад од човјека одбија такве мисли, рад што исцрпљује снагу, и сунце што убија мозак, онда се чује само звек мотике о тврду, упечену земљу, или једнолични шум косе кад ваља оштрим сјечивом за собом ниску, мршаву, брдску траву, или кад писне коса кад запара тврд камен. А ноћ потискује такве мисли знојнога рада и умора, она омамљује чељаде да заборави дневни труд и муку, она буди оно што се чинило да је успавано, на најдоњем дну душе, она је будила и у иначе мирној души Смиље Тадићеве страстан осјећај од кога је и топло и хладно. (MILIĆEVIĆ 1904: 1203)

Заборавиће на село, на оца, на браћу. Они неће бити равни њој. Она ће се возати у кочијама, становаће у великим кућама. На њој ће да шушти свила, а по џеповима ће јој звецкати новац.

Ox, како һе она, послије неколико година затвора, да се баци у тај понор замамног гријеха, да ужива тај живот што се највише уживати даде, да се утопи у том мору уживања што је без краја, без дна, велико, непрегледно море што несито мами своје жртве, то вјечно море гријеха на чијим се валовима љуљушкају душе и брзо, али неосјетно, тону, тону...

И по њезиним образима изби руменило, крв јој живље заструја у жилама, она већ осјети загрљаје господе што је лако, фино грле, осјети њихове меке прсте, пуне прстења, како је милују по њезиним образима и сељаци joj, у том тренутку, постадоше страшно одвратни што заударају на зној, са својим грубим рукама, испуцанима од рада. (MILIĆEVIĆ 1904: 90-91)

У првом одломку опет је само прва реченица исприповедана „објективним" начином, у трећем лицу, из перспективе неименованог приповедача. Већ у другој реченици приповедач прелази на доживљени говор, предочавајући нам мисли и осећања своје јунакиње, посрнуле сеоске девојке, Смиље Тадићеве. По начину размишљања, Смиља неодољиво подсећа на Ему Бовари, а то је зато што нам је њена свест предочена на исти начин на који Флобер дочарава свест своје јунакиње. У првом одломку „у души Смиље Тадићеве” буди се „осјећај који она није могла испитати својим разумом”, јер је, као и у Емином случају, реч о јунакињи несофистициране, ограничене интелигенције: и Смиља Тадићева је жена која не реагује разумом, већ чулима. За разлику од унутрашњег доживљаја Дамјана Дамјановића, у доживљају Смиље Тадићеве, просте сеоске девојке, нема сложених, јасно артикулисаних мисли и идеја; њеном унутрашњем доживљају својствене су, баш као и Еми Бовари, чулне сензације и фантазије. Кад завири у њену свест, приповедач региструје готово искључиво чулне представе, „сунце што убија мозак”, „звек мотике о тврду, упечену земљу”, ,,једнолични шум косе кад ваља оштрим сјечивом за собом ниску, мршаву, брдску траву”, писак „косе кад запара 
Адријана М. Марчетић

тврд камен”, које упућују на Смиљину сензуалну, нерефлексивну природу. Осим тога, у унутрашњем доживљају Милићевићеве јунакиње присутне су и стереотипне фантазије, боваријевске „дневне сањарије”, какава је и фантазија из другог овде наведеног одломка из Buхора, у којем Смиља размишља како ће се, пошто издржи затворску казну због убиства детета, препустити лагодном животу скупе проститутке и тако осветити породици и сељанима. Али, као и у претходном примеру ни овде Смиљино размишљање није дато у облику јасно артикулисаних мисли, већ у форми стереотипних представа које као да су преузете из неких еротско-сентименталних романа, сличних онима које је можда читала и Ема Бовари.

У начину на који Милићевић дочарава свест своје јунакиње може се уочити још једна флоберовска црта. Ауербах је у Мимезису приметио да се једна од карактеристичних особина Флоберовог начина приповедања у Госпођи Бовари састоји у томе да приповедач „уноси оштрину у утиске” своје јунакиње. Приповедајући о Еминим мислима и осећањима, Флобер не даје „натуралистичку репродукцију њене свести”, већ „сређује” њене утиске и ,збрканост њиховог унутрашњег постојања резимира у правцу којим она и сама иде”. Другим речима, „грађу” о којој приповеда, то јест мисли и осећања, Флобер узима од Еме, али је не пушта да сама говори, већ у њено име говори он сам, својим гласом и сопственим стилом. ${ }^{2}$ Ауербах каже да у Флоберовом роману, за разлику од „многих романа у првом лицу", није реч о ,једноставној репродукцији Еминог садржаја свести, онога што она осећа тако како осећа". Од Еме, додуше, каже Ауербах, „долази светлост којом се слика осветљава, но она је и сама део слике, налази се у слици... " Језичка и наративна средства којима се Флобер служи толико су софистицирана, и стил је толико прецизан и изражајан да нема никакве сумње да то не говори Ема, већ писац. На пример, када се на једном познатом месту у роману каже да се очајној Еми чинило да јој је „сва горчина постојања сервирана на тањиру” (Tout l'amertume de l'existence lui semblait servie sur son assiette), Ауербах примећује да Ема „тако стварно осећа”, али када би то хтела то изрази, каже он, „не би тако испало”: „за такво обликовање недостаје јој оштрина и хладна исправност полагања рачуна самој себи. " Као приповедач, Флобер не настоји да верно репродукује субјективност своје јунакиње, већ да „грађу” о којој приповеда ,учини језички зрелом”. ${ }^{3}$

Ако се сада вратимо Милићевићу, видећемо да у свим горе наведеним примерима ситуација о којој се приповеда није предочена једностав-

\footnotetext{
${ }^{2}$ Ауербах о овој особини Флоберовог стила говори на једном познатом месту Мимезиса (1978: 478-481).

${ }^{3}$ AUERBAH 1978: 480.
} 
но, онако како је приповедач види, већ је дата посредно, из јунакове или јунакињине тачке гледишта. Два одломка из „Вихора” прво предочавају Смиљу Тадићеву, њен унутрашњи доживљај, а потом и ситуацију како је она сагледава. Али, при том Смиљина свест није предочена непосредно, као у унутрашњем монологу, није дата њеним речима и ,једноставном репродукцијом онога што она осећа онако како осећа". Овде не говори Смиља, већ писац. Он бира утиске, прави метафоре, стилски обликује реченице. Осећања су Смиљина, али она никад не би умела да их изрази онако како нам Милићевиће о њима приповеда. Као и Флобер, и Милићевић настоји да „грађу” коју представља - мисли и осећања своје јунакиње - учини, како би рекао Ауербах, „језички зрелом”, да „унесе оштрину у њене утиске". Наравно, оваквим начином приповедња Милићевић се не служи само када је реч о Смиљи Тадићевој; као и Флобер, он „сређује утиске” свих својих јунака, и оних једноставнијег и оних сложенијег унутрашњег света, али се специфичност његове технике можда најлакше може уочити на примеру „Вихора”, управо због јунакињиног схематског начина размишљања.

Најзад, у последњем примеру, одломку из „Млаких душа”, осим психолошке карактеризације, доживљени говор има и функцију ироничног коментара којим се разобличава глупост и морална отупелост главног јунака:

О како би он био задовољан кад би се нашли однекуд новци - откуда, то ни сам није знао - па да их метне у касу и да спокојно, трљајући руке, чека комисију. Комисија, рецимо, долази, Илија Добрић је понизно, откривене главе, дочекује, са задовољним изразом на лицу, с мирним осмјехом на уснама. Они отварају касу; пребројавају новце, прегледају књиге, а Илија Добрић их посматра само са стране, наслоњен на прозор и окрећући равнодушно какав кључић на малом прсту. Они свршавају посао, налазе све у реду, извињавају се и честитају му на његовој уредности. А он се само поклони и позива скромно господу на залогај пршута и на чашицу домаће. Међутим, већ пандур Вујо окреће пуначко прасе на загорјелом ражњу које се румени и цврчи на ватри. А господин предстојник, са зажареним очима од шљивовице, хвали и истиче, заносним ријечима, способности и врлине Илије Добрића пред задовољном комисијом... (MILIĆEVIĆ 1905: 488)

Илијино фантазирање како hе се у последњем часу неким чудом спасти од пропасти, и како ће још испасти поштењачина у очима „претстојника" и осталих чланова комисије, читавом призору даје хумористично-карикатуралан карактер. Хумористичан тон приповедања овде, у контексту доживљеног говора, оставарује се првенствено посебном употребом детаља, који су одабрани тако да разоткривају јунакову лажну 
Адријана М. Марчетић

мотивацију или су, у датом контексту, толико непотребно спецификовани да делују апсурдно. Пример прве врсте налазимо у реченици у којој се каже како Илија Добрић посматра како комисија отвара касу и пребројава новце „са стране, наслоњен на прозор и окрећући равнодушно какав кључић на малом прсту", док се наизглед непотребно гомилање детаља може приметити у реченици у којој се каже како „пандур Вујо окреће пуначко прасе на загорјелом ражюу које се румени и цзврчи на ватри" (курзив мој - А. М.).

Као и у ранијим причама, и у Бесnyћy је доживљени говор главна техника помоћу које приповедач дочарава унутрашња преживљавања свог јунака; међутим, сада је обим тих унутрашњих преживљавања толико увећан да практично заузимају цео роман. Осим у шестој глави, која је накнадно дописана за издање из 1912. године, и у којој нас приповедач упознаје са предисторијом Чехиње Ирене, сва остала збивања, од прве до последње реченице, предочена су из перспективе главног јунака: у Бесnyћy, све „пролази” кроз Гавру Ђаковића. Истовремено, обим спољашњих збивања сведен је на минимум. На самом почетку романа дознајемо да се у главном јунаку, Гаври Ђаковићу, изненада, без видљивог разлога, нешто „сломило” и натерало га да напусти Загреб и врати се у своје родно село у Лици, крај Уне. Ту он проводи дане у беспосличарењу, препуштајући се туробним мислима и сећањима на мртве родитеље и брата, шетајући крај Уне и размишљајући о изгубљеном смислу живота. Преиспитујући узроке своје меланхолије, Гавре Ђаковић настоји да изгубљени смисао пронађе у неким трајнијим вредностима, у саосећању према сиромашним и тешким радом намученим сународницима, у религији, у љубави, али му ништа од свега тога не доноси ни испуњење ни спокојство за којим жуди. Иако искрено ужива у лепоти сеоског пејзажа који га у родном крају окружује, Гавре Ђаковић је сувише отуђен од села и сељака да би смисао живота успео да пронађе у некој врсти социјалног или алтруистичког ангажмана. Исто је и са вером у Бога која му је, док је био дете, срце испуњавала топлином. Поверовавши за тренутак, да ће му вера у Бога повратити бар мало „весеља за животом”, Гавре Ђаковић одлази на литургију у сеоску црквицу, али врло брзо схвата да се нашао на погрешном месту. Он „гледаше преда се, љутећи се што сви гледају на њега, и осјети како је туђ на овом мјесту које убијаше без милости његове јутарње илузије” (MILIĆEVIĆ 1982: 77). Не само вера у Бога, већ ни љубав према жени не успева да исцели чамом обузету душу Милићевићевог јунака. Дошавши у село, он заводи припросту девојку Јеку, која га искрено воли. Иако према Јеки не гаји никаква дубља осећања, Гавре Ђаковић је заводи не само да би задовољио пожуду већ и да би топлином њене љубави, њеним „бујним животом и младошћу која се пресипа” 
(MILIĆEVIĆ 1982: 46) испунио сопствену емоционалну празнину, али му ни то не полази за руком. Убрзо после тога он равнодушно одбија и наклоност Чехиње Ирене, кћерке инжињера Панека, који руководи радовима на изградњи сеоског пута и станује у кући Гавре Ђаковића. Ђаковићеве емоције према Ирени су нешто компликованије него осећања која је гајио према Јеки. Ирена га не привлачи само у физичком смислу, већ и као сродна душа, али чак ни та дубља привлачност није довољна да га покрене из емоционалног мртвила и врати му жељу за животом. На крају романа, разочарана девојка и њен отац одлазе из села, а Гавре Ђаковић, осетивши „како је нешто умрло у њему заувјек” (Милићевић 1982: 90), продаје родитељску кућу и имање и нестаје негде у Америци.

Као и у ранијим причама, основна наративна ситуација и овде је безлично приповедање у трећем лицу; приповедач не говори у своје име, не коментарише збивања и ништа не објашњава. Чак и када не понире у свест свог јунака, приповедач настоји да створи утисак безличног и објективног приповедања. Такав је случај у опису једне загребачке кафане којим почиње роман:

Обична и свакидања гунгула у кавани; људи који се мимоилазе и поздрављају; врата која се отварају и затварају с треском; момци што журно пролазе, њишући на послужавницима шоље и чаше воде; у вику наручивања и празно ударање кугла на билијару, мијеша се ватрено и гласно расправљање пензионираца о народним питањима... Около, на својим сталним мјестима, стари гости каване, заваљени, заклоњени новинама... кадгод се, с једне стране, зачује кратка, ватрена ђачка свађа... звекне која сабља и зазвекећу мамузе... од времена на вријеме, чује се с касе женски смијех... (MILIĆEVIĆ 1982: 7)

Овакав начин описивања наставља се и у неколико следећих пасуса; опис се састоји од набрајања елемената који сачињавају дати призор, из њега су изостављени сви параметри који би могли упућивати на приповедачево присуство или на његову тачку гледишта која би могла послужити као упориште за тумачење призора у целини. Међутим, врло брзо, већ на следећој страници, приповедач уводи јунака и његову тачку гледишта и сместа прелази на приповедање о његовим преживљавањима. Сазнајемо да је Гавре Ђаковић нерасположен, мада ни сам не зна због чега, да осећа да је у њему нешто „сломљено, сатрвено, тјескобно”, и да му се градски живот „у којем се гуши већ осам година” чини „бљутав”. Затим се приповедач враћа на слике из кафане, али их сада предочава из перспективе Гавре Ђаковића, и читав призор одједном добија целовит смисао:

И његове очи гледаху са запрепашћењем сав овај свијет у кавани, који је, у једном трену, изгубио за њега свој обични изглед [...] И он с чуђењем 
Адријана М. Марчетић

посматраше мноштво ђачких лица, с картама, таковима у рукама, заваљених и без мисли; чиновника што доносе са собом задах канцеларије и дебелих протокола; утегнутих и намирисаних официра [...] И у томе свијету он је провео толико година, умирао, трунуо заједно с њима... Познавао је те људе по одијелу, шеширима, навикама; њихови гласови долазили су му гадни, њихове кретње одвратне, њихови погледи глупави. И он, за један тренутак, нађе у себи само страшну мржњу за њих и низак презир за себе. (MILIĆEVIĆ 1982: 9-10)

Описивање предмета и пејзажа помешано с приповедањем о унутрашњем преживљавању јунака својствено је Милићевићу у Бесnућy. У следећој епизоди налазимо још један сличан пример. Напустивши „бљутав” градски живот, Гавре Ђаковић се враћа у своје село у Лици, на обалама Уне, не би ли повратио животни смисао:

Синоћ он стајаше ту, неодлучан, преплашен, не вјерујући својим очима да је то његова кућа; грање је тако празно шумило, тако је био туп шум ријеке, а из куће је било нешто ледено, самртничко... И кад су му донијели кључ и кад је са шкрипом јекнула стара, зарђала и дуго недирана брава, он је осјетио зиму где му се прелијева по цијелом тијелу. [...] Њега је тиштала тјескоба у овој полумрачној и укоченој соби. Осјећао се задах старине, гробља; све је подсјећало да овдје више нема живота, већ да је био, па умро; и то осјећање живота који је ишчезнуо и гдје га није одавно било, плаши и ужасава. (MILIĆEVIĆ 1982: 19-20)

Динамичност оваквих описа, у којима су истовремено предочени и спољшњи и унутрашњи пејзажи, Милићевић постиже комбиновањем дескрипције с доживљеним говором:

Неки дан, једном неспретном кретњом оборио је случајно једну малу слику. Он се преко воље и љутито сагнуо - зар га и ти људи, објешени на зидове и затворени у оквире, почеше да сметају? - и загледао се у њу. Није ју распознао у први мах. Пришао је прозору, застртом грубом завјесом с плавим пругама. И погледа поново. То је био његов брат Милан, слика одраслог голобрадог дјечака, с укрућеним, пуним, дјетињим лицем; са безазленим озбиљним очима, у кадетској униформи; то је био он на кога није тако дуго мислио, кога није препознао; како смрт одрађ)! (MILIĆEVIĆ 1982: 21-22)

Опис предмета који се уводи у јунаково видно поље служи као „увертира“ у приповедање о јунаковом унутрашњем доживљају. Поглед на братовљеву фотографију подстиче бујицу сећања на мртвог брата, његову појаву и карактер („И кроз кућу као да одјекну братов звонки глас... као да зазвекета његова сабља... као да се помоли његово ведро, насмијано лице..." - MILIĆEVIĆ 1982: 22). Исти опис отвара и једну дужу реминисценцију у којој се приповеда о једној јунаковој непријатној препирци 
с братом, као и о догађајима који су уследили пошто је од брата добио писмо у којем га обавештава о намери да изврши самоубиство. Ове епизоде, уведене у форми јунаковог сећања стоје у функцији „продубљивања" психолошког садржаја приче о Гаври Ђаковићу, односно служе да мотивишу његов „мрачан” карактер и да донекле објасне његово депресивно расположење за које, на први поглед, не постоје довољно јасни разлози.

Посматрано у целини, у Милићевићевом приповедању најбољи су управо описи. Веома је необично колико су његове технике описивања разноврсне, суптилне и изнад свега модерне; Милићевић се служи фокализованим описима, итеративним описима, симболичним и метафоричним описима, осамостаљеним описима... Остављајући по страни несумњив приповедачки таленат, инспирацију за овако широк репертоар различитих дескриптивних техника Милићевић је могао да нађе само код француских писаца, тачније код Флобера. За разлику од традиционалнијих писаца, код Милићевића опис није само приповедање о неком спољашњем призору, он није само слика неког предмета или амбијента предочена из перспективе неког спољшњег посматрача. Као и код Флобера, опис код Милићевића постаје психонаративна техника. Предочен из перспективе самог јунака, опис је у ствари слика јунаковог унутрашњег доживљаја, он је прожет јунаковим емоцијама и изражава његово расположење. Али, опис не предочава само јунаково расположење, већ сугерише и приповедачев, односно пишчев доживљај света. То је најизразитије у симболичним детаљима којима Милићевићеви описи обилују. На пример, опис којим почиње четврта глава романа може се схватити као нека врста прикривеног ауторског коментара који преноси исто осећање промашености и узалудности живота које током читавог романа прогони и самог јунака:

Сјећао се предвечерја једног врућег љетног дана... главном улицом комешало се, мимоилазећи се, мноштво вечерњег свијета који је био изашао у своју обавезну шетњу; људи се гласно поздрављали... жене бацале погледе... средином улице пролажаше једна гомила зидарских радника пуних креча по одијелу и по изобличеним, рђавим шеширима... А кроз то мноштво, лијено и спокојно окретали се точкови на двоколним таљигама, прљавим и слупаним од дасака, пуним смећа и ђубрета, из кога је вирила једна прљава лопата; таљиге вукао један крупан, стар и лијен коњ, с обореним очима као да дријема и са амом који му поиграваше на врату; на смећу спавао је слатко млад радник, са црвеним и једрим лицем, у искрпљеном прљавом одијелу, са уздигнутим коленима и са широм опруженим рукама, са изразом задовољства на лицу: снивао је, ваљда нешто лијепо. (MILIĆEVIĆ 1982: 45) 
Већ сам по себи, опис младог радника руменог лица који слатко спава на гомили ђубрета довољно је сугестиван, а контраст на којем се заснива изражава, на флоберовски начин, фундаменталну иронију живота у којем, једно крај другог, стоје трулеж, прљавштина и смеће и, с друге стране, лепота и здравље младости. Али приповедач ипак осећа потребу да на овај призор стави посебан семантички акценат. У следећем пасусу читамо:

Гавре Ђаковић се тада тргао. Свијет који је пролазио није гледао ту поспрдну слику свога живљења, није примјећивао тај неми подсмех живота, који пролажаше полагано и неопажено. Гавре Ђаковић видио га је и осјетио га је. И тај призор не раздвајаше се више од њега, он га је прогонио свуда: кад год је загледао у свој живот, јављала се у њему злобно и пакосно та слика, само мјесто радника видио је себе. (MILIĆEVIĆ 1982: 45-46)

Овакав доживљај стварности није својствен само Гаври Ђаковићу; и други Милићевићеви јунаци, и у Бесnyћy и у ранијим и у каснијим причама, осећају да их је живот некако преварио, изневерио и подсмехнуо се њиховим илузијама и идеалима. Осећања усамљености, огорчености и несхваћености доминирају Милићевићевом прозом, а у Бесnућy не опседају само Гавру Ђаковића и његове суморне мисли, већ и друге, споредне јунаке. На пример, сељанчица Јека је преварена у дословном смислу, кад се Гавре Ђаковић коме је поклонила своју љубав загледа у другу девојку, њена очекивања су изневерена, а осећања одбачена. Слично пролази и Чехиња Ирена, али је у њеном случају мотив изневерених очекивања још наглашенији, јер се на њему заснива цела прича о Ирениној предисторији која нам је предочена у VI глави романа. Ту сазнајемо да је Ирена, пошто ју је мајка оставила и ,препустила оцу који се ... пропио и живио са својом вешерком”, осетила „како је живот неправедан и опор”: „Она страдаше за туђу кривицу, она је била несрећна ради другога, она с ужасавањем гледаше како тону сви њезини снови и нестају у непомичној помрчини из које бије хладноћа што слеђиваше душу.” (MILIĆEVIĆ 1982: 83) Најзад, несрећан је и разочаран чак и чеховљевски јунак, инжињер Панек, који се са сопственим животним разочарењима носи честим опијањима и извештаченом жовијалношћу. У Бесnућy практично нема личности којој нека „невидљива паучина” није „села на срце” и „нагризла” јој и „исцрвоточила” вољу за животом (MILIĆEVIĆ 1930: 45), нема ниједне једине светле тачке, ни најмањег наговештаја срећног расплета, суочени с бесмислом живота, ни споредни јунаци ни сам Гавре Ђаковић не проналазе излаз из животног беспућа. На крају романа, писац их једноставно уклања из читаочевог видокруга - Гавру Ђаковића шаље у Америку, Панека и његову кћер у Чешку - не нудећи никакву перспективу која би евентуално могла да послужи као компензација за изгубљени 
животни смисао. Зато слободно можемо рећи да метафора из наслова романа у потпуности оправдава осећање безизлазности и бесперспективности које доминира Милићевићевим светом. Наравно, то суморно осећање живота не одликује само Гавру Ђаковића, оно је својствено самом писцу чији је сензибилитет извор светла у којем се сагледава укупно значење приче о Гаври Ђаковићу, младићу са села, студенту пуном идеала, трагично изгубљеном у потрази за смислом живота.

Горе наведени опис младог радника који безбрижно спава на гомили ђубрета представља увод у епизоду у којој нам је, у слободном индиректном стилу, предочено како Гавре Ђаковић размишља о смислу живота. Карактеристично је да су јунакове мисли „помешане” са идиличним описом Уне и сеоског пејзажа, који су такође предочени из јунакове перспективе. Лепота пејзажа наводи га на помисао да би „можда било боље да се није одвајао од своје земље”, да би можда ту пронашао срећу и да „не би можда осјећао оволико празнине у животу” (MILIĆEVIĆ 1982: 47). У различитим тумачењима Милићевићевог романа ова размишљања Гавре Ђаковића, као и читава ова епизода, заузимају средишње место. Готово у целини ово место цитира и Скерлић у приказу Бесnућа из 1912. То је и разумљиво будући да је ово једино место у роману на којем се читаоцу нуди некакво објашњење за туробно јунаково расположење. Али, иако је ово место са становишта тумачења романа у целини несумњиво важно, не смемо да заборавимо да је оно предочено као размишљање самог јунака, у форми доживљеног говора, па би било брзоплето закључити да јунаково размишљање подупире и приповедачево тумачење предочених збивања.

У „мемли и чами” провинцијске „плитке средине”, Гавре Ђаковић се осећа „сам, одвојен од свега, као у једној страшној бескрајној пустињи без хоризонта":

Гурнули су га у школе да буде господин, одвојили су га од земље и народа, спријечили га да ухвати коријена у земљи из које је изникао, гурнули га у један живот у који кад је загледао, он се згрозио, ужаснуо, тргнуо. И пошао је натраг кад већ више мостова није било: у онај живот није се усудио да уђе, а овај други постао му је неприступан. И он је застао, остао тако стојећи, не идући ни напријед ни натраг, с презривим осмијехом према себи, са рукама на леђима, осјећајући горко сву биједу и глупост свога положаја. (MILIĆEVIĆ 1982: 48)

На основу ових редова Скерлић закључује да је Милићевић кроз лик свог јунака хтео да прикаже једну у оно време популарну књижевну идеју, идеју о „човеку без корена”. Под утицајем Мориса Бареса и његовог романа Les Déracinés, њу су у југословенским књижевностима, каже Скерлић, већ развијали Вјенцеслав Новак у Tumy Дорчићу и Милутин Ус- 
коковић у Дошљьацима. Али, наставља он, Милићевићу није пошло за руком да причу о човеку истргнутом из корена предочи у форми „социјалног” романа, односно да понуди уверљиву анализу јунаковог друштвеног преображаја. Код Милићевића нема социолошке анализе, он је „више дао дело моралног посматрања, психолошке анализе, рашчлањивања наизменичних стања свести једног бедног младог неурастеничара". Иако са великим уважавањем говори о Милићевићевом таленту за психолошку анализу и „моралну аутопсију”, Скерлић ово одсуство социјалне или тачније, социјално ангажоване димензије, рачуна у један од озбиљнијих недостатака Беспућа: „Његов јунак не пати зато што је из 'корена истргнут', но просто зато што је пометен, 'понесен па упуштен', оријенталски 'бадаваџија' и словенски мрљавац, који своју урођену лењост, неспособност и нерад прикрива свакојаким 'проблемима'... Вељко Милићевић није успео да нам свог кукавног јунака представи као жртву једног тешког социјалног преображаја, прилагођавања једне младе расе условима модернога живота.” (SKERLIĆ 197: V, 296-297)

У тумачењу Бесnyћa и други критичари су често посезали за идејом о „човеку без корена”. Драгиша Витошевић каже да је у српској критици о Милићевићевом јунаку постојала представа „скоро искључиво као о 'човеку без корена"' (VITOŠEVIĆ 1982: 140). Навешћемо само неколико примера. Милош Видаковић у приказу Беспућа, објављеном такође 1912, у часопису Народ, каже да је у лику Гавре Ђаковића Милићевић створио књижевног јунака који је „постао типичан за целу једну групу људи коју зову déracinés” (наведено према PEKOVIĆ 1989: 45). По Живку Милићевићу, идеја о „човеку коме корен није урастао у земљу” обележава целокупно предратно стваралаштво Вељка Милићевића. Различити Милићевићеви јунаци отеловљују овај тип: Дамјан Дамјановићу у „Мртвом животу”, Гавре Ђаковић у Бесnyћy, Бранко Завишић у Onсенама. Овог последњег Живко Милићевић сматра „најближим духовним сродником Гавре Ђаковића" (Ž. MILIĆEVIĆ 1930: XXIII, XXVII). У прилог оваквим тумачењима, осим одломка који смо овде цитирали, Драгиша Витошевић наводи још нека места из Бесnућа, између осталог и оно где се каже како Гавре Ђаковић „жуди да се врати земљи, да се баш 'укорени' као нека биљка, 'да и њега пржи суша и изгара припека"' (VITOŠEVIĆ 1982: 141). Витошевић ипак није сасви склон да Милићевићевог јунака без остатка сведе на тип „човека без корена”. Он с правом примећује да начин на који нам је овај јунак предочен није искључиво типски. Разлоге Ђаковићевог отуђења не треба тражити само у губитку „корена”, већ и у читавом низу других егзистенцијалних траума, односу према оцу и брату, мајчиној емоционалној хладноћи, неспособности да се оствари у љубави... Није све у „раскорењености”, каже Витошевић, 
ту је „и цео низ других 'одвајања'” које по њему такође морамо узети у обзир у тумачењу Ђаковићевог лика (VITOŠEVIĆ 1982: 142). Иако је на бољем путу од Скерлића и осталих критичара, ни Витошевићево тумачење није сасвим прихватљиво.

По спољашњој, егзистенцијалној ситуацији, Гавре Ђаковић би се заиста могао узети као пример „човека без корена”. Пореклом са села, из интелектуално сиромашне породице, Ђаковића одлази на школовање у Загреб: „Гурнули су га у школе да буде господин, одвојили су га од земље и народа, спријечили га да ухвати коријена у земљи из које је изникао, гурнули га у један живот у који кад је загледао, он се згрозио, ужаснуо, тргнуо." Али, видели смо да су ове речи део епизоде у којој, у форми доживљеног говора, јунак преиспитује своје осећање животне промашености; оне не морају нужно изражавати и приповедачево становиште. Штавише, када треба разјаснити зашто је у његовом јунаку „умрла воља за све”, приповедач је врло уздржан и нигде у роману изричито не каже зашто се у њему одједном све „сломило”. Милићевић у ствари уопште не обликује свог јунака као типичног „човека без корена”; Гавре Ђаковић је и нешто мање и нешто више од тога. С једне стране, њему недостају социјална амбиција и извесна морална неосетљивост које по правилу одликују типичног „раскорењеног човека”. С друге стране, по сензибилитету, сложености унутрашњег живота и капацитету за самоанализу, он је много сложенији и у сваком случају потпуно друкчији од типичног parvenu-a. Пре него тип, Гавре Ђаковић је индивидуалиста, јунак који трага за смислом живота, али не у друштвеним и моралним стереотиповима, већ у болном и тегобном самопреиспитивању, у сопственој души, „у страшној бескрајној пустињи без хоризонта” (MILIĆEVIĆ 1982: 48).

Ослањајући се више на спољашње него на чисто књижевне критерије, Скерлић је то пропустио да уочи. У приказу из 1912. године он у Гаври Ђаковићу више није видео израз једног потпуно новог, индивидуалистичког сензибилитета, већ само „оријенталског 'бадаваџију' и словенског мрљавца, који своју урођену лењост, неспособност и нерад прикрива свакојаким 'проблемима"' и зато му није био нимало симпатичан (SKERLIĆ 1964: V, 297). Он је замерио Вељку Милићевићу што „није успео да нам свог кукавног јунака представи као жртву једног тешког социјалног преображаја, прилагођавања једне младе расе условима модернога живота", не помишљајући да овоме то можда није ни била намера и не питајући се није ли можда управо у том „промашају” била садржана највећа иновативност и вредност овог романа. Ипак, у једном се можемо сложити са Скерлићем: Бесnyћe је много више психолошки роман но роман из друштвеног живота. Али, у томе не треба видети његов недостатак. Напротив, управо такав какав јесте, уроњен у танану психолошку 
анализу од прве до последње странице, овај роман представља сасвим оригиналну појаву у српској књижевности прве деценије 20. века. И данас он изгледа модеран и нов управо по својој радикалној посвећености психолошкој анализи и „моралној аутопсији” једног нетипичног, потпуно самосвојног јунака.

\section{Цитирана литература}

AUERBAH 1976: АУЕРБАХ, Е. (1976). Мимезис, Београд.

VITOŠEVIĆ 1982: ВИТОШЕВИЋ, Д. (1982). Поговор за Бесnуће В. Милићевића, Београд.

MILIĆEVIĆ 1903: МИЛИЋЕВИЋ, В. (1903). Мртви Живот, Српски књижевни гласник, бр. 5 - 1. новембар, 1903 - 1. јануар 1904;

MILIĆEVIĆ 1930: МИЛИЋЕВИЋ, В. (1930). Приповетке I и II. Београд.

MILIĆEVIĆ 1982: МИЛИЋЕВИЋ, В. (1982). Бесnуће. Београд.

MILIĆEVIĆ Ž. 1930: МИЛИЋЕВИЋ, Ж. (1930). Поговор за Приповетке I В. Милићевића, Београд.

MOPASAN 1903: МОПАСАН, Ги де (1903). Орла, Мостар, превод В. Милићевић.

PEКОVIĆ 1989: ПЕКОВИЋ, С. (1989). Кюижевно дело Вељка Милићевића, Београд.

SKERLIĆ 1964: СКЕРЛИЋ. J. (1964). Писичи и књиге IV и V, Београд.

Adrijana M. Marčetić

\section{NARRATIVE TECHNIQUES IN VELJKO MILIĆEVIĆ'S FICTION}

At the very beginning of the 20th century Veljko Milićević was one of the most celebrated young writers of Serbian literature. Although he was only fifteen when he published his first literary work he immediately attracted the attention of literary critics. His first story, „Mrtvi život“" Milićević published in the most renowned Serbian literary magazine at the time, Srpski književni glasnik", in 1903; after that the entry to the main stream of Serbian literature was widely opened to him. With his first novel, „Bespuće“ (1906), Milićević acquired a reputation of the most prominent representative of the new generation of Serbian poets and writers. Jovan Skerlić correctly observed that Milićević's fiction represented an entirely new literary sensibility, characteristic to the young, 
talented writers who just started to enter the literary scene. The period between 1903 and 1906 was the most fruitful in Milićević's literary career. But in the following years, he practically stopped publishing, and soon his early fame begun dissolving. Once one of the greatest hopes of Serbian modern literature, after the Great War Milićević and his first novel were almost completely forgotten. This was a serious loss for the history of Serbian literature since Milićević was a true innovator: he was the fist to introduce one completely new subject in Serbian fiction - introspection, and a completely new narrative technique psychonarration. Steeped into the psychological analysis from the first to the last letter, Milićević's novel represents an entirely innovative phenomenon in Serbian literature of the beginning of the 20th century. Even today it is very modern and fresh due to its radical commitment to the psychological autopsy of an atypical, completely idiosyncratic character.

In this paper I investigate narrative techniques Milićević used to represent the inner life of his characters. Apart from objective third person narration, his main instruments for this purpose were free indirect speech and descriptive techniques such as focalised description and iterative description.

Keywords: Veko Milićević, "Bespuće", experienced speech, focalized description, a man without roots 